\title{
pnmbalina
}

(8)

\section{The banquets of Alexander}

Autor(es): $\quad$ Mestre, Francesca; Gómez, Pilar

Publicado por: Imprensa da Universidade de Coimbra; Centro de Estudos Clássicos e

URL

persistente: URI:http://hdl.handle.net/10316.2/31997

DOI: $\quad$ DOI:http://dx.doi.org/10.14195/978-989-8281-17-3_19

Accessed : $\quad$ 26-Apr-2023 12:12:03

A navegação consulta e descarregamento dos títulos inseridos nas Bibliotecas Digitais UC Digitalis, UC Pombalina e UC Impactum, pressupõem a aceitação plena e sem reservas dos Termos e Condições de Uso destas Bibliotecas Digitais, disponíveis em https://digitalis.uc.pt/pt-pt/termos.

Conforme exposto nos referidos Termos e Condições de Uso, o descarregamento de títulos de acesso restrito requer uma licença válida de autorização devendo o utilizador aceder ao(s) documento(s) a partir de um endereço de IP da instituição detentora da supramencionada licença.

Ao utilizador é apenas permitido o descarregamento para uso pessoal, pelo que o emprego do(s) título(s) descarregado(s) para outro fim, designadamente comercial, carece de autorização do respetivo autor ou editor da obra.

Na medida em que todas as obras da UC Digitalis se encontram protegidas pelo Código do Direito de Autor e Direitos Conexos e demais legislação aplicável, toda a cópia, parcial ou total, deste documento, nos casos em que é legalmente admitida, deverá conter ou fazer-se acompanhar por este aviso. 


\section{Symposion and Philanthropia in Plutarch}

\section{José Ribeiro Ferreira, Delfim Leão Manuel Troster e Paula Barata Dias (eds.)}

IMPRENSA DA UNIVERSIDADE DE COIMBRA 


\title{
The banquets of Alexander
}

\author{
Pilar Gómez \& Francesca Mestre \\ University of Barcelona
}

\begin{abstract}
Banquet scenes are often described in Plutarch's Lives. In the Life of Alexander, Plutarch defines the exemplary profile of the Macedonian king in his relations with others - his companions and friends and his defeated enemies. The social institution of symposium, so deeply rooted in the Greek tradition, is used as an instrument to highlight certain aspects of Alexander's "Greekness", either to contrast them with the customs of the barbarians, or, alternatively, to confirm that the conqueror fully adopted barbarian ways.

In spite of the fact that Alexander behaves immoderately at banquets, Plutarch neither criticizes him openly nor censures him; the behaviour should not be taken as belonging to Alexander's $\tilde{\eta} \theta 0$, but to the changes that he introduces in the Greek tradition itself.
\end{abstract}

The ritualized act of sharing food and drink played an important role in the social, political and religious cohesion of Archaic and Classical Greece, since the banquet, either public or private, offered an occasion to strengthen ideologicallinks and friendships ${ }^{1}$. Due to the economic outlay that it represented and the time it required, the private symposium was associated above all with an aristocratic lifestyle; it was a reunion inter pares in an exclusively masculine environment ${ }^{2}$.

Equally, the size of the group that participated in the symposiac gathering - and the venue - had a direct effect on the nature of the loyalties inside

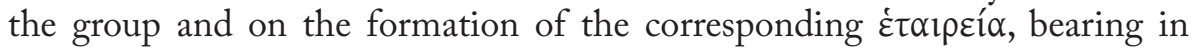

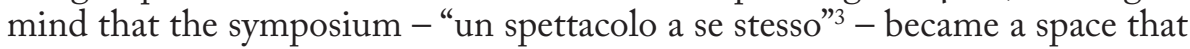
was outside the polis, with specific rules and norms of its own. Examples are its distinct treatment of sexuality, both in terms of the homoerotic relations established among the young in the closed setting of the banquet - in parallel with the gymnasium and the palaestra -, the creation of a kind of free love associated with the hetairae and artists who customarily attended symposia, and the development of forms of ritual exhibitionism and violence inherent in the event's final $\kappa \tilde{\omega} \mu \varsigma^{4}$.

From the fourth century onwards, the decline of the cities and the changes in the forms of power were often attributed to the extreme luxury in which the richest sectors of society lived. This impression was greatly reinforced by the tales of the fabulous banquets of the Hellenistic monarchies, which were obvious examples of the transformation that the institution of the symposium had undergone. This explains why Plutarch speaks so highly of the private

${ }^{1}$ Cf. P. Schmitt-Pantel, 1992, pp. 13-117.

${ }^{2}$ The Etruscans and Romans admitted their wives and daughters to their banquets; the Greeks regarded this as a clear example of their lack of education and morality; cf. Theopomp. Hist. FGH 115 F 204; Cic., Ver. 2.1.64-66.

${ }^{3}$ Cf. L. E. Rossi, 1983.

${ }^{4}$ Cf. E. Pellizer, 1990, pp. 182-3. 
banquet as a privileged space where knowledge and friends could meet, a place where diners come "to share not only meat, wine, and dessert, but conversation, fun and the amicability that leads to friendship" .

The discussions and entertaining talk would take place during the symposiac stage per se of the banquet ${ }^{6}$, in which wine always played a central role. The wine was not an end in itself but the prologue to speech - in particular, of the philosophical speech that was an integral part of the symposium and

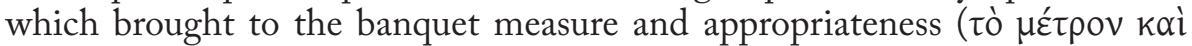

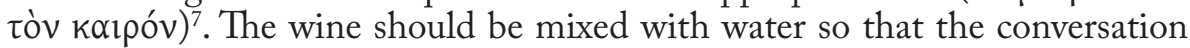
and the entertainment could last as long as possible, and to prevent the misbehaviour that might ensue from excess, distorting the true aim of the banquet and disrupting the harmony of the meeting. Indeed, the drinking of pure wine was considered to be a practice of barbarian peoples ${ }^{8}$.

The controversial figure of Alexander the Great plays a key role in the contraposition between the Greek and the non-Greek, and, to an extent, constitutes a point at which this duality undergoes a change in direction. As has been noted elsewhere ${ }^{9}$, Plutarch's presentation of Alexander changes as his oeuvre progresses: that is, he does not apply the same analytical parameters in the Moralia as in his extensive biography of the Macedonian king. In treatises such as On the fortune of Alexander, influenced by the rhetorical tradition of the conqueror and the ideology of the Flavian dynasty, Plutarch presents a vindication of the Macedonian king whose mission is to carry out a vast geopolitical project involving the fusion of various territories; later, while writing the Life, Plutarch appears to enjoy greater freedom in his presentation of Alexander as a model and reference point for Roman emperors.

In this article we explore the Life of Alexander in order to establish how and to what extent the banquet - the place in which Plutarch's heroes may display moral virtues such as $\varphi \imath \lambda i ́ \alpha$ or $\varphi \imath \lambda \alpha v \theta \rho \omega \pi i^{10}{ }^{10}$ contributes to defining the exemplary profile of the Macedonian king in his relations with others, both his companions and friends and his defeated enemies. In this way we aim to determine whether Plutarch uses this social institution, so deeply rooted in the Greek tradition, as an instrument to highlight certain aspects of Alexander's "Greekness" and to contrast them with the customs of the barbarians, or, alternatively, to confirm that the conqueror fully adopted barbarian ways.

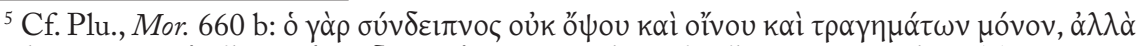

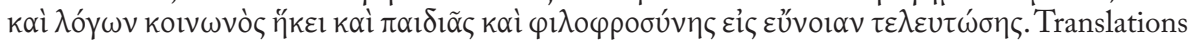
of Table Talks are by Clement \& Hoffleit (LCL).

${ }^{6}$ From the Hellenistic era onwards, however, the contacts first with Macedonia and later with Rome linked erudite discussion to the meal; cf. Ath. IV.

${ }^{7}$ Cf. Plu., Mor. 613 b. On the connection between wine and the word, see L. Romeri, 2002, pp. 171-89.

${ }^{8}$ Cf. O. Murray, 1990, p. 6.

${ }^{9}$ Cf. L. Prandi, 2000, pp. 385-6.

${ }^{10}$ Cf. F. Frazier, 1996, pp. 233-6. 
Banquet scenes are often described in Plutarch's Lives and take on a variety of functions ${ }^{11}$. Following the tradition of Plato and Xenophon, Plutarch is particularly interested in the ethics of the symposium, presided over by controlled enjoyment, friendship, and the freedom of speech ${ }^{12}$. With its flexibility and its duality (it may be public or private, formal or informal, comic or tragic) the banquet becomes an appropriate setting for Plutarch's narration of some of the episodes in the biographies. The banquet serves as the backdrop for the discussion of political questions, for murdering one's enemies, for impressing one's friends and one's adversaries - or making fun of them, or drawing attention to their differences -, as a meeting-place for lovers, and so on. The symposium, then, offers Plutarch an ideal opportunity to reveal the true characters of his heroes, perhaps because it is a context in which individuals behave in consonance with their true nature ${ }^{13}$. This may have been why Pericles did not attend the banquets in the homes of his friends during his political career: "Conviviality is prone break down and over power the haughtiest reserve, and in familiar intercourse the dignity which is assumed for appearance's sake is very hard to maintain"14.

In the Life of Alexander banquet scenes appear time and again to highlight the conduct, culture and character of its protagonist, whose liking for wine in fact formed part of his legend ${ }^{15}$. Plutarch devotes one of his Table Talks (I 6) to Alexander's drinking, and reports that the conversation with Philinus

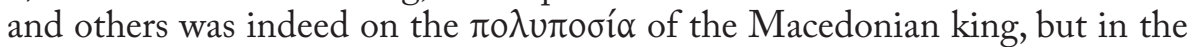
sense that "he did not drink excessively, but did spend much time in drinking and conversing with his friends" 16 . Nonetheless, Plutarch's Philinus denies this, stating that in the royal Journal, compiled by Eumenes of Cardia and Diodotus of Erithras, "it is written, 'after a bout of drinking Alexander slept this day through', sometimes with the addition of 'and the following day also'. Accordingly he was very lazy about love-making, though his bold and choleric temperament indicated a hot-natured body"17. Plutarch also states that one of the reasons why Callisthenes earned himself the enmity of Alexander was that he did not share the king's liking for pure wine, remarking "that he did not wish to drink from Alexander's cup and so stand in need of Asclepius's"18.

${ }^{11}$ Cf. G. Paul, 1991 who presents a catalogue of anecdotes that took place during the celebration of a banquet in the Parallel Lives; cf. also L. Romeri, 2002, p.173.

${ }^{12}$ Cf. T. Whitmarsh, 2002, p. 182.

${ }^{13}$ Cf. F. Titchener, 1999, p. 499.

${ }^{14}$ Cf. Plu., Per. 7.5.

${ }^{15}$ Cf. Ath. 434 b; Ael., VH 3.23.

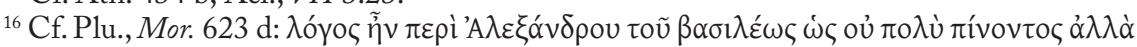

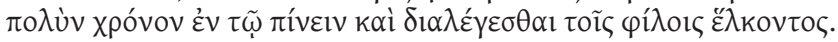

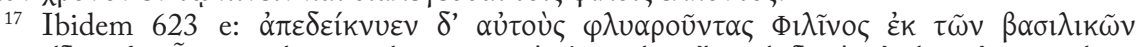

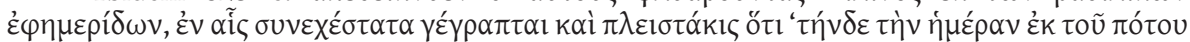

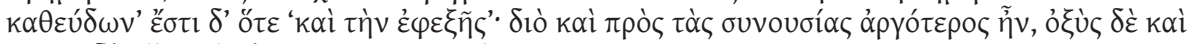

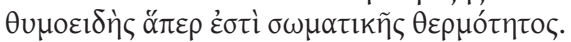

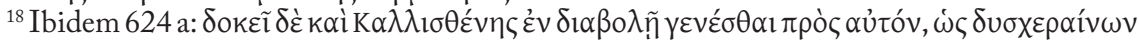

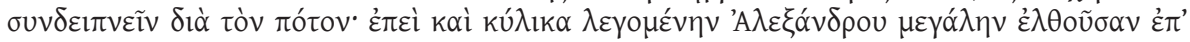


Let us look now at several particularly significant episodes in Macedonia, Persepolis and Samarkand.

In Plutarch's Life, the first banquet that serves as the background to a manifestation of Alexander's character is the one held at the Macedonian court to mark the wedding of Philip to the young Cleopatra, after the king's repudiation of Olympias on suspicion of infidelity. In this symposiac scene - devoid of any amicable conversation - it is Alexander's antagonists who are inebriate. Despite his youth, Alexander reveals a passionate and spirited nature $\left(\theta v \mu \text { ozi } \delta \eta^{\prime}\right)^{19}$ as he defends his legitimate status as heir to the Macedonian throne; he insults Attalus and laughs at his father who is too drunk to stand up, while he, Alexander, appears to be unaffected by the wine. Attalus, the uncle of the bride, "being in his cups" ( $\dot{\varepsilon} \nu \tau \tilde{\omega} \pi$ ró $\tau \omega \mu \varepsilon \theta u ́ \omega v$, Alex. 9.7 ${ }^{20}$, proposes an ill-chosen toast, urging the Macedonians to pray to the gods to bless the union of Philip and Cleopatra with an heir to the

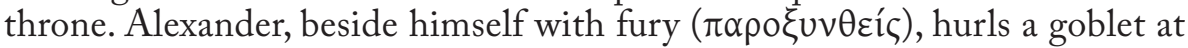
him and shouts at him: "But what of me, base wretch? Dost thou take me for a bastard?" 21 . Hearing this insult, Philip stands up, his sword in his hand, and makes for his son, but, "fortunately for both, his anger and his wine made him trip and fall”. Alexander, in his insolence $(\dot{\varepsilon} \varphi \cup \beta \rho i ́ \zeta \omega v)$ exclaims sarcastically: "Look now, men! here is one who was preparing to cross from Europe into Asia; and he is upset in trying to cross from couch to couch" 22 . This scene confirms, then, that the explosiveness of Alexander's character is due to his nature, not due to his liking for wine.

After describing Alexander's extraordinary triumph at the battle of Issus (333 BC), Plutarch briefly interrupts his narration of historical events to highlight Alexander's exemplary treatment of the Persian royal captives Darius' mother, his wife, and his two unmarried daughters. With them the

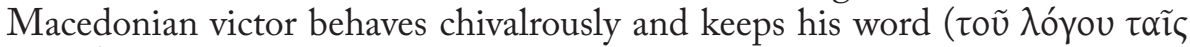

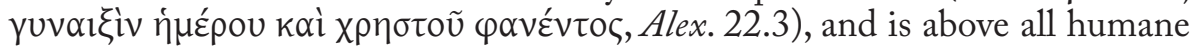

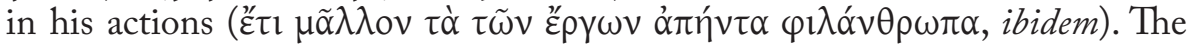
meeting takes place when Alexander is going to dine. Despite the daughters' extraordinary beauty, the Macedonian treats them with respect and does not even deprive them of honours, since - in the opinion of Plutarch - "it would seem, considering the mastery of himself a more kingly thing that the conquests of his enemies" 23 . Alexander also shows presence of mind in his treatment of the other captives, who also have a fine bearing: "Persian women were torments to the eyes." - he says - but Plutarch adds that the king "displaying in rivalry

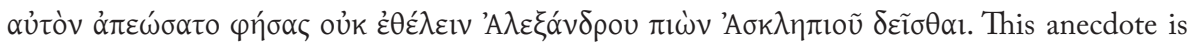
also found in Athenaeus (X $434 \mathrm{~d}$ ).

${ }^{19}$ Cf. T. Duff, 1999 , p. 85.

${ }^{20}$ Translations of Life of Alexander are by Perrin (LCL).

${ }^{21}$ Cf. Plu., Alex. 9.8.

${ }^{22}$ Ibidem 9.10.

${ }^{23}$ Ibidem 21.7. 
with their fair looks the beauty of his own sobriety and self-control, he passed them by as though they were lifeless images for display"24.

In this same context Plutarch devotes an entire chapter to Alexander's conception of drinking and banqueting. In an echo of the Table Talk (I 6) Plutarch now says that Alexander spent a long time on each drink, devoting more time to talking than to drinking, and drinking only in times of leisure, "for in the stress of affairs he was not be detained, as others commanders were, either by wine, or sleep, or any sport, or amour, or spectacle"25. So, Plutarch presents Alexander as a perfect host, concerned that his guests be served as equals and in abundance, and repeats that the drinking was spread over a long period of time, for the sake of the conversation ${ }^{26}$.

However, Plutarch recognizes in the next paragraph of the Life that under the effects of wine the Macedonian conqueror acts like any other soldier and abandons himself to boasting and adulation, to such an extent that the success of the banquet is put at risk. This places the diners of a finer spirit in a particularly awkward situation, wishing neither to compete with the flatterers nor to appear reticent in their praise, since the former course appears shameful to them and the latter dangerous ${ }^{27}$. After the bout of drinking, Alexander would wash and sleep profoundly until midday, and on occasion would spend the entire day asleep, as we saw in the Table Talk mentioned above ${ }^{28}$.

Excessive drinking can lead to the death of somebody, as in the case of Cleitus, in an episode which Whitmarsh ${ }^{29}$ considers emblematic of Alexander's progressive decline into barbary and which reveals how Alexander has begun his slide into decadence by renouncing Greek austerity for Eastern luxury. It is no coincidence that the episode occurs after Alexander has begun to adopt Persian dress and other attributes ${ }^{30}$. In this scene, Alexander runs Cleitus through with a spear; Cleitus, "who was already drunk and naturally of a

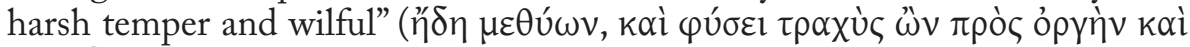

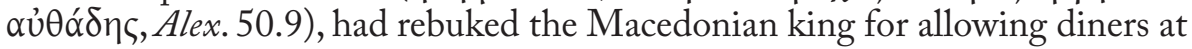
the banquet to sing verses mocking the Macedonian generals who had recently been defeated by the barbarians at the siege of the acropolis of Maracanda ${ }^{31}$. Far from the camaraderie and relaxed atmosphere characteristic of a banquet, the confrontation between Alexander and Cleitus, his loyal friend and companion who had even saved his life at the battle of the Granicus, provokes uproar. The

${ }^{24}$ Ibidem 21.10. The good treatment given by Alexander to the Persian captives is also recorded in Ps.-Callisth. II 22.

${ }^{25}$ Ibidem 23.1-2.

${ }^{26}$ Ibidem 23.6. Plutarch (Mor. 620 a-622 b) devotes the fifth question of the first book of the Table Talks to a discussion of the ideal nature of the director of a banquet, a figure who was essential to the success of the celebration; cf. P. Gómez \& M. Jufresa, 1999, pp. 261-3.

${ }^{27}$ Ibidem 23.7.

${ }^{28}$ Cf. Plu., Mor. 623 e; Ath. X 434 b.

${ }^{29}$ Cf. T. Whitmarsh, 2002, p. 182.

${ }^{30}$ Cf. Plu., Alex. 45.

${ }^{31}$ Cf. Arr., An. IV 3.7. 
king commands Cleitus to be silent, but Cleitus refuses, and invites Alexander "to speak out freely what he wished to say, or else not to invite to supper men who were free and spoke their minds, but to live with Barbarians and slaves, who would do obeisance to his white tunic and Persian girdle"32.

Plutarch places side by side the freedom of speech - the $\pi \alpha \rho \rho \eta \sigma i ́ \alpha$ as a key component of the Greek symposium ${ }^{33}$ - and the verbal or physical violence deriving from a lack of self-control in both Cleitus and Alexander. It is also interesting to see how Cleitus celebrates this banquet context, understood as a free conversation between equals, as the centre of "his" model of Hellenicity which he refuses to abandon in order to follow his king. Cleitus formulates this

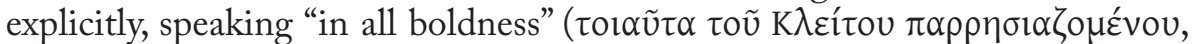
Alex.51.3), and saying that he envies the Macedonians who died before seeing Alexander give way to Persians and Medes. However, at the same time, Plutarch seems to suggest that Alexander has his own model of Hellenicity which, going beyond the norms of an ancient institution such as the banquet, consists precisely in integrating new lands inside the Hellenic structure. Cleitus's death at the hands of Alexander during the banquet is an example of excess against the moderation, restraint, kindness and friendship which, for Plutarch, should always preside over the relations between the participants at a symposium: a death that represents everything that Alexander's model of Hellenicity wishes to leave behind. It is clear that in this celebration it is not the word as a vehicle for education that conditions action, but violence; but since Plutarch is not excessively critical of this violence, what the episode in fact shows, in our view, is the difficulty of adapting the immutability of the Hellenic to the outside world, to the context beyond the classical polis; a new context in which Greeks, Macedonians and Barbarians act at the same level.

In Plutarch's account - the episode has not survived in the version by Diodorus Siculus - it is Cleitus who provokes the king with words. Alexander responds with actions, and there is no doubt that his reaction is excessive. Plutarch, however, wishes to excuse Alexander: the act was performed in a moment of fury, when he had lost control of his senses. So, like Ajax when he realizes that he has not killed Odysseus, Alexander, when he realizes what he

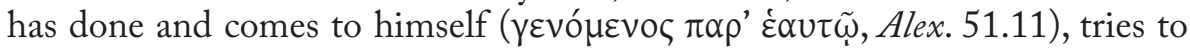
commit suicide, only to be prevented by his companions and friends; he spends the night weeping and the next day says not a word until the philosophers Callisthenes and Anaxarchus of Abdera are brought to him to alleviate his suffering. Anaxarchus consoles Alexander for the murder saying that Zeus also has Dike and Themis seated next to him, so that all that is done by a king appears legitimate and just ${ }^{34}$. Nonetheless, in the treatise To an uneducated ruler Plutarch presents Anaxarchus as an example of a flattering philosopher; he states that a sovereign should be more afraid of doing wrong than suffering

${ }^{32}$ Cf. Plu., Alex. 51.5.

${ }^{33}$ Cf. W. Rösler, 1995, pp. 108-9.

${ }^{34}$ Plutarch's contemporary Dio of Prusa compares the government of a good king with that of Zeus as well, cf. D.Chr. I 37-41, II 75-78, III 51-53, IV 40-43. 
it, while before Alexander "neither correct nor helpful were the means he [Anaxarchus] took in endeavouring to heal the king's remorse for his sin, by encouraging him to further acts of the same sort" ${ }^{35}$. Underlying this anecdote, however - and going beyond the strictly literal interpretation - we find one of the favourite themes not only of Plutarch but of other writers of the era: the virtues of the good ruler. Naturally enough, one of the virtues of the good ruler is the ability to impose his will when necessary, in spite of the opposition of those around him $^{36}$, even if a certain amount of violence is required.

So, as we have seen, , Plutarch excuses Alexander of the murder of Cleitus, which he considers to have occurred not "of set purpose, but through some

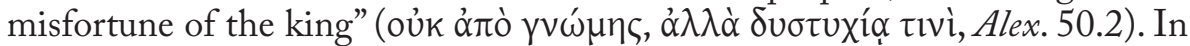
justifying the king's behaviour, then, Plutarch just links the king's misfortune

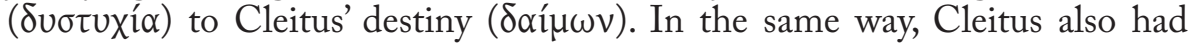
attributed the defeat of the Macedonian generals sent to put down the revolt in the Sogdian region to misfortune $(\delta v \sigma \tau u x i ́ \alpha)^{37}$ not to cowardice $(\delta \varepsilon \imath \lambda i ́ \alpha)$, when he tried to restore the honour of the fallen in the face of the scorn heaped on them by the other diners - which Alexander did nothing to stop (Alex. 50.9-10). In so doing, Cleitus only brings on his own death ${ }^{38}$.

The recognition of his murder leaves Alexander speechless and filled with remorse. In this way, also, Plutarch maintains the link between philosophy that is, philosophical themes and the men who devote themselves to them - and the banquet, understood as a space in which philosophy verifies in

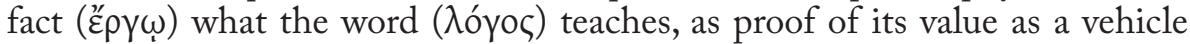
for education, as it is presented in Table Talk $\mathrm{I}^{39}$. However, in the biography, and facing such a problematic affair, Plutarch wishes to make clear that the position of philosophers is not always convenient: Anaxarchus is blamed for increasing Alexander's vanity and lawlessness, and for being indulgent with his whims, whereas Callisthenes, after the death of Cleitus, alleviates the king's pain by considerate and gentle methods, employing insinuations

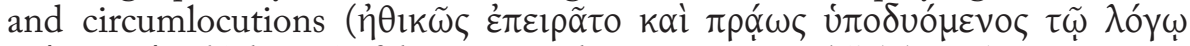

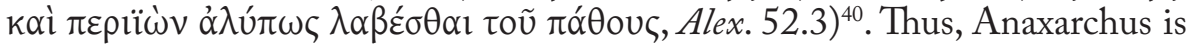
described as arrogant and inconsiderate towards his associates, a philosopher who had always followed a path of his own - in clear contrast to Callisthenes, who finally falls foul of the Macedonian king in spite of giving clear signs of

${ }^{35}$ Cf. Plu., Mor. 781 b. However, in Mor. 331 e, Plutarch reports that Anaxarchus was the friend that Alexander held in most esteem - precisely as an example of the king's love of wisdom.

${ }^{36}$ Cf. D.Chr. II 71-72.

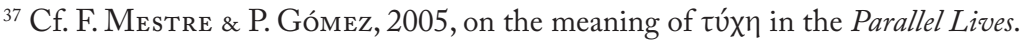

${ }^{38}$ Cf. Plu., Alex. 52.4. Nonetheless, on another occasion, Plutarch describes Cleitus as an example of vainglory ("when he had scuttled three or four Greek triremes at Amorgos, caused himself to be proclaimed Poseidon and carried a trident", Mor. 338 a), which he contrasts with Alexander's sobriety in matters of state, "nor was he made drunk nor led to revelling by authority and power" (Mor. $337 \mathrm{f})$.

${ }^{39}$ Cf. Plu., Mor. 613 c; L. Romeri, 2002, p. 275; E. SuÁrez de la torre, 2005, p. 480.

${ }^{40}$ Cf. J. M. Mossman, 1988, pp. 88-90. 
leading an ordered, dignified and independent life, and in spite of his renown as an orator ${ }^{41}$.

Perhaps for this reason Plutarch uses the figure of Callisthenes to question

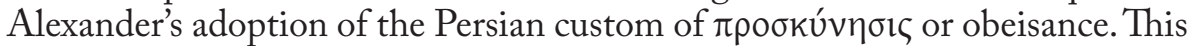
custom was an act of homage in recognition of the sovereign's rank, but it was interpreted by the Greeks as an exaggerated act of veneration, treating the king as a god. On the subject of the obeisance, Plutarch notes that Callisthenes was the only man who in the presence of Alexander "rehearsed in public the reasons for the indignation which all the oldest and best of the Macedonians cherished in secret" ${ }^{42}$. Like Cleitus, Callisthenes became the victim of his own $\pi \alpha \rho \rho \eta \sigma i ́ \alpha$ by acting ill-manneredly, appearing to want to force the king, rather than to persuade him, to give up this barbarian custom.

Callisthenes'open rejection of obeisance appears again during the banquet, when Alexander, after drinking, hands the cup to a friend who takes it, makes obeisance to the king, kisses him and resumes his place on the couch. All the guests do the same, until it is Callisthenes' turn; he takes the cup, drinks, and goes towards the king to kiss him. Informed by Demetrius that Callisthenes had not honoured him, Alexander refuses the kiss -Plutarch notes that Alexander had been distracted, conversing with Hephaestion.

Alexander's friends - men like Hephaestion, Lysimachus and Hagnon - close ranks around him; Callisthenes is the object of slander and false accusations and is implicated by his detractors in Hermolaus' failed conspiracy against Alexander ${ }^{43}$. Callisthenes's refusal to make obeisance "by refusing

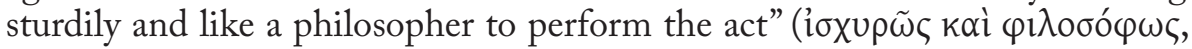
54.3), is interpreted by Whitmarsh not so much as an ethical analysis of Alexander's conduct, already contaminated by barbarian practices, but as an example of how philosophy resists submitting to power ${ }^{44}$; again we see how the ancient model of the banquet, an ideal institution for "philosophy", seems to have difficulty in maintaining its position in a new context. Nonetheless, on another occasion, Cassander incurs the wrath of Alexander by laughing at some barbarians making obeisance to their king, since he "had been reared as a Greek and had never seen such a sight as this before" ${ }^{45}$. Again, Greek and Barbarian customs are found in opposition in the context of the banquet.

An excess of wine is also present in Alexander's death. The king has overcome his grief for the death of Hephaestion - also caused by drinking "a huge cooler of wine" ${ }^{46}$. In the biography, after participating in a splendid

${ }^{41}$ Cf. Plu., Alex. 53.1.

${ }^{42}$ Ibidem 54.3.

${ }^{43}$ Hermolaus, son of Macedonian nobles, was a member of Alexander's bodyguard. He was severely punished for flouting protocol during a hunt. Seeking vengeance, he and his companions agreed to kill the monarch while he slept. Hermolaus may also have been urged on by the philosophers who disapproved of Alexander's orientalization (cf. Arr., An. IV 13.2).

${ }^{44}$ Cf. T. Whitmarsh, 2002, p. 184.

${ }^{45}$ Cf. Plu., Alex. 74.3.

${ }^{46}$ Ibidem, 72.2 . 
banquet in honour of Nearchus, Alexander is persuaded by Medius to attend another feast where he drinks all night and the following day: Plutarch states that Alexander did not finish "the bowl of Heracles", but fell victim to a high fever, and felt a great thirst; he drank wine and became delirious, until finally he died ${ }^{47}$. However, Diodorus Siculus states that at this feast, which Alexander attended in the company of his friend Medius, the king drank a large quantity of pure wine ${ }^{48}$, and drank a great bowl of Heracles, down to the last drop ${ }^{49}$.

The barbarization of Alexander mentioned in some of the passages above - all of them related to the symposiac context: interdict of $\pi \alpha \rho \rho \eta \sigma i \alpha$; obligation of $\pi \rho \circ \sigma \kappa u ́ v \eta \sigma \iota \varsigma$; drinking pure wine, ... - contrasts with the respect for Greek tradition that, in Plutarch's account, the Macedonian king displays in Persepolis, also during the course of a celebration. During a feast, the Attic courtesan Thais proposed that they set fire to the palace of Xerxes in order to avenge the burning of Athens during the Persian invasion of the fifth century BC. Alexander is easily persuaded, and he himself "with a garland on his head and a torch in his hand, led them the way" ${ }^{50}$. Plutarch suggests that there were several reasons for his action, among them the fact that burning the palace and destroying it was a clear sign of the will of someone who is not intending to settle in barbarian lands - perhaps it is no coincidence that the episode of the palace fire occurs just before Alexander adopts Persian dress ${ }^{51}$. For this reason, Plutarch states that the Macedonian king repented immediately and ordered the fire to be put out ${ }^{52}$. Again, the version of Diodorus Siculus differs here, as he presents Alexander in a much more exalted state because of the drink consumed at the splendid feasts that he prepared for his friends, at the head of a Dionysiac retinue which, led by Thaïs, set fire to the Persian royal palace $^{53}$.

Alexander's conduct in the symposiac context does not reveal an exemplary paradigm of the Greek tradition. He is by no means a model guest or a magnificent host. For Plutarch, the director of the feast must be a good drinker, neither inclined to drunkenness nor an enemy of wine; he must be aware that he is leading a group of friends; he must make it possible for the guests to engage in serious discussion and jocular speech; and, like a pleasant wine, without being sour, should have a natural tendency towards gravity

${ }^{47}$ Ibidem 75.6. In the narration of the king's death, Plutarch explicitly mentions his source, Aristobulus, as he considers that other versions have been invented by those who felt it necessary to create a tragic end, worthy of a great drama.

${ }_{48}$ Alexander also served pure wine at the wedding of his companions celebrated at Susa with a splendid banquet for nine thousand guests, each one of whom was given a gold cup for the libations; cf. Plu.Alex. 70.3

${ }^{49}$ Cf. D.S. XVII 117.

${ }^{50}$ Cf. Plu., Alex. 38.6.

${ }^{51}$ Ibidem 45; cf. D.S. XVII 77.

${ }^{52}$ Cf. Plu., Alex. 38.8.

${ }^{53}$ Cf. D.S. XVII 72; Arr. An. III 8. 
and austerity, which will make him respectable; but as the wine softens and smooths him, his temper will be pleasant and agreeable ${ }^{54}$.

For all these reasons, even though Plutarch repeatedly justifies Alexander's conduct in the symposium - so often lacking in restraint - it is significant that in one of the few symposiac scenes in the Life of Alexander in which drink is associated with the moment after dinner when the conversation proper begins $^{55}$ (a discussion of climate and the temperature of the atmosphere), one of the interlocutors should be Callisthenes ${ }^{56}$, the king's friend, but also the victim of his wrath.

As many scholars have noted ${ }^{57}$, the historical value of the Life of Alexander suffers from a clear inconsistency. More than a biography, the account appears to be dominated by a taste for adventure and character analysis of the hero, whose successes Plutarch is keen to portray as due not to the whims of Fortune but to the protagonist's efforts and character. In this biography, then, the writer attempts to defend Alexander against his detractors even to the extent of justifying inexcusable acts - as we have highlighted in the case of the death of Cleitus or the king's animadversion towards Callisthenes - although on other occasions his tone is openly critical ${ }^{58}$.

The Life of Alexander, then, describes several occasions on which Alexander behaves immoderately at banquets. Plutarch, however, neither criticizes him openly nor censures him; the behaviour should not be taken perhaps as belonging to Alexander's $\tilde{\eta} \theta$ os, but to the changes that he introduces in the Greek tradition itself. It is, in our opinion relevant, that, in his attempt to define Alexander as a king and as the man that has hellenized the world, Plutarch chooses the frame of the banquet to show his significant $\tilde{\eta} \theta$ os, with all the hesitations and contradictions that such an achievement involves. Alexander seems to be obliged to kill Cleitus but immediately after he feels regret over the loss of a friend; he imposes $\pi \rho \circ \sigma k u ́ v \eta \sigma ı \zeta$ as a sign of obeisance even if he knows that it is something ridiculous for a Greek; he wants to burn the Palace of Xerxes to revenge the burning of Athens but puts out the fire immediately. It is as if Alexander were forced to restrain his natural being in order to succeed in his hellenizing goal.

${ }^{54}$ Cf. Plu., Mor. 620 a-622 b; and supra note 26.

55 Cf. P. A. Stadter, 1999, for an analysis of how in the Table Talks Plutarch tells his contemporaries of the advantages of those symposia in which the drinking of wine was combined with good conversation, but does not directly attack the dissipation and drunkenness that characterized certain circles in his times.

${ }^{56}$ Cf. Plu., Alex. 52.8.

${ }^{57}$ Cf. J. Sirinelli, 2000, pp. 313-16.

${ }^{58}$ Cf. Plu., Alex. 42.4, where Plutarch states that Alexander was increasingly preoccupied with his fame rather than with his life or his kingdom, and therefore behaved cruelly and inexorably; or 57.3, where he states that at the time of the preparations for the invasion of India, Alexander was feared by his men because of the terrible punishments he meted out. 
In fact, these banquet scenes, in our view, stress two interrelated themes: first, the model of Hellenicity, and therefore of Hellenization, that Alexander wishes to impose; and second, the virtues of the good ruler - an issue of particular interest to the authors of the Empire ${ }^{59}$. The banquet, then, can be taken as a symbol of the ancient Hellenic institutions, the institutions which Alexander will now adapt in his attempts to make the Hellenic universal.

\section{WORKS CITED}

Duff, T., Plutarch's Lives. Exploring Virtue and Vice, Oxford, 1999.

Frazier, F., Histoire et morale dans les Vies parallèles de Plutarque, Paris, 1996.

Gómez, P. \& Jufresa, M., "La risa y el vino en los escritos simposíacos de Plutarco", in J. G. Montes Cala et al. (eds.), Plutarco, Dioniso y el vino, Actas del VI Simposio Español sobre Plutarco (Cádiz, 14-16 de Mayo, 1998), Madrid, 1999, pp. 255-67.

Mestre, F. \& Gómez, P., "Tyche e individuo: ambigüedad de usos en las Vidas Paralelas de Plutarco", in A. Pérez Jiménez \& F. Titchener (eds.), Valori letterari delle Opere di Plutarco. Studi offerti al Professore Italo Gallo dall' International Plutarch Society, Málaga-Utah, 2005, pp. 295-306.

Murray, O. (ed.), Sympotica. A symposium on the Symposion, Oxford, 1990.

Mossman, J. M., "Tragedy and Epic in Plutarch's Alexander", JHS, 108 (1988) 83-93.

Paul, G., "Symposia and Deipna in Plutarch's Lives and in Other Historical Writings", in W. J. Slater (ed.), Dining in a Classical Context: Contrast and Parallels, Ann Arbor, 1991, pp. 157-69.

Pellizer, E., "Outlines of a Morphology of Sympotic Entertainment", in O. Murray (ed.), Sympotica. A symposium on the Symposion, Oxford, 1990, pp. 177-83.

Prandi, L., "L'Alessandro di Plutarco (Riflessioni su De Al. Magn. Fort. e su Alex.)", in L. VAN DeR Stockt (ed.), Rhetorical Theory and Praxis in Plutarch, Leuven, 2000, pp. 375-86.

Romeri, L., Philosophes entre mots et mets. Plutarque, Lucien et Athénée autour de la table de Platon, Grenoble, 2002.

Rösler, W., "Wine and Truth in the Greek Symposion", in O. Murray \& M. Tecușan (eds.), In vino veritas, Oxford, 1995, pp. 106-12.

${ }^{59}$ Alexander is in fact the protagonist of two of Dio of Prusa's speeches on kingship: one of them $(O r . \mathrm{II})$ is a dialogue between a young Alexander and his father Philip, while the other $(O r$. IV) evokes a meeting between the king and Diogenes the Cynic. 
Rossi, L. E. "Il simposio greco arcaico e classico come spettacolo a se stesso", in Centro di studi sul teatro medioevale e rinascimentale (eds.), Spettacoli conviviali dall'antichità classica alle corti italiane del' 400. Atti del VII Convegno di Studio, Viterbo, 1983, pp. 41-50.

Schmitt-Pantel, P., La cité au banquet, Rome, 1992.

Sirinelli, J., Plutarque, Paris, 2000.

Stadter, P.A., "Drinking, Table-Talk, and Plutarch's Contemporaries", in J. G. Montes et Al. (eds.), Plutarco, Dioniso y el vino, Actas del VI Simposio Español sobre Plutarco (Cádiz, 14-16 de Mayo, 1998), Madrid, 1999, pp. 481-90.

SuÁrez de la Torre, E., "Diálogo, filosofía y simposio en Plutarco", in M. Jufresa et Al. (eds.), Plutarc a la seva època: paideia i societat. Actas del VIII Simposio español sobre Plutarco, Barcelone, 2005, pp. 463-84.

Titchener, F., "Everything to do with Dionysus", in J. G. Montes Cala et AL. (eds.), Plutarco, Dioniso y el vino. Actas del VI Simposio Español sobre Plutarco (Cádiz, 14-16 de Mayo, 1998), Madrid, 1999, pp. 49199.

Whitmarsh, T., “Alexander's Hellenism and Plutarch's Textualism”, $C Q, 52$ (2002) 174-92. 